430005, г. Саранск, ул. Большевистская, 68.

Тел.: (8342) 25-41-79.

Ерофеев Владимир Иванович, д-р биол. наук, проф., проректор по учебно-методической работе, Мордовский институт переподготовки кадров агробизнеса. Россия.
430904, г. Саранск, п/о Ялга, ул. Пионерская, 33. (8342) 25-37-40.

Ключевые слова: порода; живая масса; телки; протеин; рацион; уровень кормления; среднесуточный прирост.

\title{
INFLUENCE OF THE LEVEL OF FEEDING ON THE DYNAMICS OF GROWTH OF HEIFER OF RED-MOTLEY BREED
}

VelmatovAnatoliyAnatolyevich, Candidate of Agricultural Sciences, Researcher, Mordovia Research Institute of Agriculture. Russia

VelmatovAnatoljyPavlovich, Doctor of Agricultural Sciences, Professor, Leading Researcher. Mordovia Research Institute of Agriculture. Russia

Mungin Vladimir Viktorovich, Doctor of Agricultural Sciences, Professor of the chair "Zootechnics", National Research Mordovia State University named after N.P. Ogarev. Russia.

Tishkina Tatiana Nikolaevna, Candidate of Agricultural Sciences, Senior Teacher of the chair "Technology of Production and Processing of Agricultural Products", National Research Mordovia State University named after N.P. Ogarev. Russia.

Afonina Olga Vladimirovna, Post-graduate Student of the chair "Technology of Production and Processing of Agricultural Products", National Research Mordovia State University named after N.P. Ogarev. Russia.

Erofeev Vladimir Ivanovich, Doctor of Biological Sciences, Professor, Mordovia Institute for Retraining of Agribusiness Personnel, Russia.
Keywords: breed; live weight; heifers; protein; diet; feeding level; daily average gain.

The article presents the results of growing heifers at different levels of feeding. Studies have shown that red-motley animals are able to increase live weight at a young age, which indicates the precocity of animals. At three months of age, heifers of the 1st experimental group outperform their analogues in live weight from the control group by $15.0 \mathrm{~kg}$, at 6 months of age by $38.9 \mathrm{~kg}$, at 9 months of age by 42.3 $\mathrm{kg}$, and at 12 months of age by $66,4 \mathrm{~kg}$ and at the age of 13 months when reaching a live weight of $377 \mathrm{~kg}$ were inseminated. The heifers of the second experimental group exceeded their peers in similar age periods by $6.2 \mathrm{~kg} ; 24.5 \mathrm{~kg} ; 34.1$ and $55.2 \mathrm{~kg}$. The heifers of the third experimental group had an advantage in the same age periods by 3.5; 17.6; 16.0 and $29.8 \mathrm{~kg}$. The advantage of the heifers of the fourth experimental group is not significant and not reliable. Heifers from the control group gained the required live weight of $380 \mathrm{~kg}$ at the age of 17 months.

\section{МОЛОЧНАЯ ПРОДУКТИВНОСТЬ И ГЕТЕРОГЕННОСТЬ В ЕАВ, ЕАҒ ЛОКУСАХ БУРОГО ШВИЦКОГО СКОТА}

\author{
ГОНТОВ Михаил Елисеевич, Федеральное государственное бюджетное научное учреждение \\ «Федеральный научный центр лубяных культур»
}

\section{кольцОВ Дмитрий Николаевич, Федеральное государственное бюджетное научное} учреждение «Федеральный научный центр лубяных культур»

Приведены результаты изучения молочной продуктивности бурого швицкого скота Смоленской области в зависимости от гомозиготного и гетерозиготного состояния маркерных генов ЕАВ и ЕАF локусов групп крови. Исследования проводили с использованием стандартных иммуногенетических и статистических методов с применением реагентов собственного производства. Установлено, ито с увеличением молочной продуктивности первотелок в популяиии снижается относительное количество животных, гомозиготных в ЕАВ-локусе, и выявляется их недостаток. Гетерозиготные животные превосходили гомозиготных по надою молока за 305 дней первой лактации. Группа коров, гомозиготных по аллелю

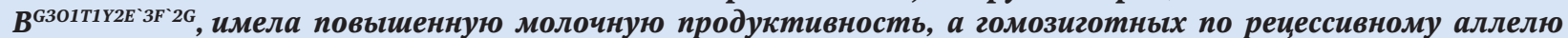
ЕАВ-локуса - пониженную. Животные, гетерозиготные по $F / V$-локусу групп крови, по уровню удоя за 305 дней первой лактации (4849 к2), продолжительности продуктивного использования (свыше 13 лактаций), количеству молока, полученного за всю продуктивную жизнъ коровы (26 452 -75 792 кг), превосходили аналогов, гомозиготных по этому локусу.

Введение. В настоящее время перед животноводами России стоит задача обеспечения населения страны молочными продуктами собственного производства. В условиях снижения поголовья дойного стада решающее значение для повышения объемов реализации приобретает повышение молочной продуктивности крупного рогатого скота. На уровень удоя и качественные показатели молока оказывают влияние генетические и паратипические факторы. Только определенные генотипы при соответствующих условиях внешней среды могут формировать организмы животных с высокой жизненной энергией, способных продуцировать длительное время большое количество молока.

Выявление, сохранение и накопление генов, положительно коррелирующих с продуктивными признаками, позволят получать животных, 
генотипы которых определяют более высокие показатели продуктивности в каждом последующем поколении. Таким образом, в процессе эволюции человеку удалось, на первых порах интуитивно, используя сведения о фенотипах, a в дальнейшем целенаправленно, усовершенствовать крупный рогатый скот до проявления очень высоких, наследственно закрепленных показателей молочной продуктивности.

При аддитивном влиянии на признак такие гены, при целенаправленном отборе и подборе родительских пар, накапливаясь в поколениях животных, усиливают проявление признака. Теоретически этот процесс должен сопровождаться повышением уровня гомозиготности. При комбинативном влиянии проявление признака у потомства усиливается определенным сочетанием родительских генов, за счет повышения гетерозиготного состояния организма.

Для оценки наследственных особенностей животных, определения степени гетерозиготности используют генетические маркеры, которые позволяют следить за генетической информацией, прямо или косвенно выявлять гены, оказывающие влияние на молочную продуктивность коров и тем самым повышать эффективность селекционной работы $[16,18]$.

В ходе проведенных ранее исследований была установлена возможность использования групп крови в качестве генетических маркеров для повышения темпов селекции. При этом большая часть исследований посвящена изучению взаимосвязей между маркерными генами локусов ЕАВ и ЕАС и продуктивными признаками $[6,12]$. Отдельные исследования посвящены изучению уровня гомозиготности в поколениях, при этом отмечено повышение уровня гетерозиготности животных, проявляющих наиболее высокую продуктивность по удою [4].

В селекции молочного скота уделяется большое внимание коровам с рекордными показателями молочной продуктивности, потомство от которых, как правило, оставляют для дальнейшего разведения. Такой подход вполне оправдан тем, что высокопродуктивное животное имеет набор генов, определяющих высокую продуктивность. Эти гены селекционеры стараются сохранить и размножить через потомков, используя генеалогические схемы.

Наряду с высокой молочной продуктивностью за отдельную лактацию на экономическую эффективность отрасли в целом влияет пожизненная продуктивность животных [13]. На физиологическую возможность животных давать много высококачественного молока на протяжении длительного промежутка времени оказывают влияние генетические и средовые факторы [14].
Идентифицировать генетические факторы помогают группы крови, с помощью которых подтверждают достоверность записей происхождения племенных животных; определяют генетическую дифференциацию пород, линий и родственных групп; оценивают генотипы быков-производителей для выявления желательных наследственных факторов с целью использования в селекционных целях; определяют генетическое сходство и различия между животными, популяциями, породами; выявляют в раннем возрасте фримартинизм телок; контролируют передачу генов от родителей потомкам; подбирают родительские пары для получения потомства с желательными генами; определяют уровень гомозиготности как отдельных животных, так и целых групп $[1,2,3,5,8,9,10,15,19)]$.

Проведенные нами исследования, направленные на использование групп крови в качестве генетических маркеров для определения влияния гетерогенности организмов животных в отдельных локусах групп крови на уровень молочной продуктивности и продолжительность продуктивного использования бурого швицкого скота смоленского типа, являются актуальными. Новизна исследований состоит в изучении уровня молочной продуктивности и продолжительности хозяйственного использования коров бурого швицкого скота смоленского типа в зависимости от гомозиготности и гетерозиготности животных в ЕАВ и ЕAF локусах групп крови.

Цель данной работы - изучение молочной продуктивности коров бурой швицкой породы в зависимости от гомозиготного или гетерозиготного состояния в ЕАВ и ЕАF локусах групп крови и влияния генотипов EAF-локуса на продуктивное долголетие и уровень молочной продуктивности.

Методика исследований. В ходе исследований определяли группы крови маточного поголовья бурой швицкой породы; устанавливали генотипы животных и распределяли коров на опытные группы; определяли продолжительность использования коров разных генотипов.

Исследования проводили с 1985 по 2019 г. в лаборатории зоотехнологий Федерального государственного бюджетного научного учреждения «Федеральный научный центр лубяных культур» на маточном поголовье бурого швицкого скота смоленского типа племзавода «Доброволец» численностью 1664 головы.

Получение и унификацию диагностикумов для определения групп крови, определение групп крови осуществляли общепринятыми методами [17]. Аллели, генотипы и фактическую гомозиготность животных в ЕАВ-локусе выявляли семейным анализом, а теоретическую гомозиготность - с использованием формулы [7]:

$$
C a_{j}=\sum_{j=1}^{n} q^{2}
$$


где $C a_{j}$ - теоретический уровень гомозиготности для одного локуса; $n$ - число аллелей в локусе (системе); $q$ - частота встречаемости аллеля.

Гомозиготных животных в EAF-локусе определяли по результатам гемолитических тестов прямым подсчетом. Молочную продуктивность коров и продолжительность их хозяйственного использования устанавливали по базе данных Селэкс. Биометрическую обработку экспериментальных данных проводили на основе методических указаний $[\mathbf{7}, 11]$, компьютерной программы Microsoft Excel. Анализ продуктивного долголетия осуществляли на животных, полностью закончивших продуктивную жизнь.

Результаты исследований. Для выявления возможной зависимости молочной продуктивности от уровня гомозиготности в ЕАВ-локусе групп крови распределяли первотелок на 5 групп (с разницей 1000 кг удоя между группами). Определяли в каждой группе уровень фактической гомозиготности и рассчитывали теоретически ожидаемый уровень гомозиготности (табл. 1).

При удое менее 3000 кг молока на корову за 305 дней первой лактации фактическое количество гомозиготных животных соответствовало расчетным данным. В группах первотелок с удоем 3001 кг молока и выше фактический коэффициент гомозиготности был значительно ниже теоретического. Так, в группах коров с удоем свыше 5000 и 6000 кг разница между теоретически рассчитанным коэффициентом гомозиготности и фактическим составила 0,034 и 0,102 соответственно. Анализ удоя коров за 305 дней лучшей лактации показал аналогичную тенденцию сокращения доли гомозиготных животных при повышении уровня молочной продуктивности, особенно в группах коров с удоем от 6000 до 10000 кг.

Анализ спариваний родительских пар с учетом их генотипов в ЕАВ-локусе, от которых получены исследованные первотелки, выявил в потомстве значительные расхождения между теоретически рассчитанным количеством животных с гомозиготным локусом и фактическим наличием.
Теоретически, чтобы получить одного потомка (например, гомозиготного) по аллелю $\mathrm{G}_{3} \mathrm{O}_{1} \mathrm{~T}_{1} \mathrm{Y}_{2} \mathrm{E}_{3}{ }_{3} \mathrm{~F}_{2} \mathrm{G}^{\prime}{ }^{\prime}$, необходимо провести 4 спаривания родителей, у каждого из которых должен быть аллель $\mathrm{G}_{3} \mathrm{O}_{1} \mathrm{~T}_{1} \mathrm{Y}_{2} \mathrm{E}_{3}{ }_{3} \mathrm{~F}_{2} \mathrm{G}^{\prime}{ }^{\prime} . \mathrm{B}$ наших исследованиях на одно гомозиготное животное приходится 8 таких спариваний родительских пар, то есть наблюдаемое количество гомозигот в два раза меньше, чем рассчитанное теоретически. Полученные данные свидетельствуют о преимуществе животных с гетерозиготным состоянием ЕАВ-локуса.

Для более объективной оценки влияния на уровень молочной продуктивности коров состояния генотипа и снижения влияния факторов внешней среды исследовали молочную продуктивность первотелок, родившихся только в 1996-2000 гг. Годы первой лактации этих животных характеризовались примерно одинаковыми условиями кормления и содержания. В дополнение к ЕАВ-локусу, для анализа молочной продуктивности коров в зависимости от гомозиготности, использовали также EAF-локус групп крови (табл. 2). Исследований по этому локусу проведено мало. Особенностью ЕАF-системы групп крови является возможность визуально определять генотип животного, по результатам гемолитического теста. У каждого животного может быть только один генотип из трех возможных: гомозиготный - F/F или V/V, гетерозиготный - F/V.

По данным табл. 2, гетерозиготные первотелки в ЕАВ-локусе превосходят сверстниц по величине удоя за 305 дней первой лактации на 278 кг, а по содержанию жира в молоке - на 0,03 \%. При анализе животных, различающихся гомозиготностью в EAF-локусе, установлена разница по удою в пользу гетерозиготных (F/V) первотелок - 280 кг молока; различий в жирномолочности и белковомолочности не установлено.

Поскольку разные аллели ЕАВ-локуса маркируют разный наследственный материал животных, молочная продуктивность гомозиготных животных может зависеть от специфики аллеля, по которому животное гомозиготно. В результате анализа установлена группа из 13 гомозигот-

Таблица 1

Сравнение фактического и ожидаемого уровня гомозиготности в ЕАВ- локусе у первотелок разной продуктивности

\begin{tabular}{|l|c|c|c|c|c|c|}
\hline \multicolumn{1}{|c|}{ Показатель } & До 3000 кг & $3001-4000$ кг & $4001-5000$ кг & $5001-6000$ кг & Свыше 6000 кг & В среднем \\
\hline$n$ & 103 & 401 & 558 & 353 & 49 & 1464 \\
\hline $\begin{array}{l}\text { Фактический уровень } \\
\text { гомозиготности }\end{array}$ & 0,078 & 0,083 & 0,104 & 0,074 & 0,041 & 0,087 \\
\hline $\begin{array}{l}\text { Ожидаемый уровень } \\
\text { гомозиготности }\end{array}$ & 0,078 & 0,094 & 0,109 & 0,108 & 0,143 & 0,104 \\
\hline Разница & 0 & 0,11 & 0,05 & 0,034 & 0,102 & 0,017 \\
\hline
\end{tabular}

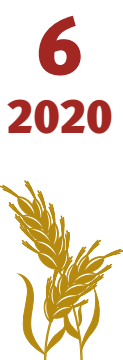


Молочная продуктивность первотелок в зависимости от гомозиготности локусов ЕАВ и EAF

\begin{tabular}{|c|c|c|c|c|c|c|c|}
\hline \multirow{2}{*}{ Показатель } & \multicolumn{2}{|c|}{ ЕАВ -локус } & \multirow{2}{*}{$\begin{array}{c}\text { Гомо- } \\
\text { Зиготы } \\
\text { F/F }\end{array}$} & \multirow{2}{*}{$\begin{array}{c}\text { Гетеро- } \\
\text { зиготы } \\
\text { F/V }\end{array}$} & \multirow{2}{*}{ По группе } & \multicolumn{2}{|c|}{ Гомозиготы } \\
\hline & $\begin{array}{c}\text { гомо- } \\
\text { зиготы }\end{array}$ & $\begin{array}{l}\text { гетеро- } \\
\text { зиготы }\end{array}$ & & & & b & $\mathrm{G}_{3} \mathrm{O}_{1} \mathrm{~T}_{1} \mathrm{Y}_{2} \mathrm{E}_{3}{ }_{3} \mathrm{~F}_{2}^{\prime} \mathrm{G}^{\prime \prime}$ \\
\hline$n$ & 25 & 361 & 231 & 136 & 403 & 13 & 8 \\
\hline Удой, кг & $3957 \pm 191$ & $4235 \pm 51$ & $4105 \pm 62^{*}$ & $4385 \pm 85^{*}$ & $4219 \pm 43$ & $3522 \pm 171^{*}$ & $4849 \pm 286^{*}$ \\
\hline Жир, \% & $3,82 \pm 0,01^{*}$ & $3,85 \pm 0,01^{*}$ & $3,85 \pm 0,01$ & $3,84 \pm 0,01$ & $3,85 \pm 0,01$ & $3,80 \pm 0,04$ & $3,79 \pm 0,02$ \\
\hline Белок, \% & $3,27 \pm 0,01$ & $3,27 \pm 0,01$ & $3,27 \pm 0,01$ & $3,28 \pm 0,01$ & $3,27 \pm 0,01$ & $3,28 \pm 0,02$ & $3,23 \pm 0,02$ \\
\hline
\end{tabular}

* разница достоверна при $p \leq 0,05$.

ных животных по рецессивному (b) аллелю и группа из 8 гомозиготных животных по аллелю $\mathrm{G}_{3} \mathrm{O}_{1} \mathrm{~T}_{1} \mathrm{Y}_{2} \mathrm{E}_{3} \mathrm{~F}_{2} \mathrm{G}^{\prime \prime}{ }_{2}$. При сравнении показателей молочной продуктивности этих групп выявлено значительное превосходство первотелок, у которых в гомозиготном состоянии находился аллель $\mathrm{G}_{3} \mathrm{O}_{1} \mathrm{~T}_{1} \mathrm{Y}_{2} \mathrm{E}_{3} \mathrm{~F}_{2} \mathrm{G}^{\prime}{ }_{2}$ (см. табл. 2). Удой коров этой группы составил 4849 кг молока и превышал аналогичный показатель сверстниц, гомозиготных по рецессивному аллелю, на 1327 кг, при равном содержании жира в молоке, но содержание белка было на 0,05 \% ниже.

Исследования показали, что первотелки, гомозиготные по рецессивному аллелю, были самыми низкопродуктивными. При удое 3522 кг молока за лактацию они на 697 кг уступали сверстницам по выборке и на 435 кг гомозиготным животным. Поэтому при подборе следует отдавать предпочтение такому сочетанию родительских пар, при котором исключается рождение потомства, гомозиготного по рецессивному ЕАВ-аллелю.
Анализ уровня жирномолочности коров-первотелок в зависимости от гомозиготности в EAF-локусе не выявил связи между этими показателями (табл. 3).

Продуктивное долголетие коров зависит от многих факторов внешней и внутренней среды. Чтобы длительное время продуцировать большое количество молока, животное должно иметь идеальное состояние всех функционирующих систем организма, которое устанавливается определенным генотипом и созданием необходимых условий для его проявления. Для определения продолжительности продуктивного использования коров бурой швицкой породы в зависимости от генотипа в EAF-локусе групп крови выбывших животных стада распределили на три опытных группы. Первую группу составили гомозиготы F/F, вторую - гетерозиготы F/V, третью - гомозиготы V/V (табл. 4).

Установили, что состояние гетерозиготности EAF-локуса оказывало влияние на продолжи-

Содержание жира в молоке коров, различающихся генотипами ЕAF-локуса, \%

\begin{tabular}{|l|c|c|c|c|c|c|c|}
\hline \multicolumn{1}{|c|}{ Показатель } & До 3,6 & $3,6-3,7$ & $3,8-4,0$ & $4,0-4,2$ & $4,3-4,4$ & Свыше 4,4 & В среднем по стаду \\
\hline$n$ & 105 & 502 & 588 & 175 & 62 & 29 & 1461 \\
\hline $\mathrm{F} / \mathrm{F}$ & 0,676 & 0,544 & 0,537 & 0,6 & 0,581 & 0,759 & 0,563 \\
\hline $\mathrm{F} / \mathrm{V}$ & 0,286 & 0,41 & 0,43 & 0,36 & 0,403 & 0,241 & 0,4 \\
\hline $\mathrm{V} / \mathrm{V}$ & 0,038 & 0,046 & 0,033 & 0,04 & 0,016 & 0 & 0,037 \\
\hline $\begin{array}{l}\text { Гомозиготы } \\
(\mathrm{F} / \mathrm{F} \text { и V/V) }\end{array}$ & 0,71 & 0,59 & 0,57 & 0,64 & 0,60 & 0,76 & 0,60 \\
\hline
\end{tabular}

Таблица 4

Продолжительность продуктивного использования бурых швицких коров с учетом EAF-генотипов

\begin{tabular}{|c|c|c|c|c|c|c|c|}
\hline \multirow{3}{*}{$\begin{array}{c}\text { Продолжительность } \\
\text { использования, } \\
\text { лактаций }\end{array}$} & \multicolumn{6}{|c|}{ Генотипы EAF-локуса групп крови } & \multirow{3}{*}{$\begin{array}{c}\text { Все } \\
\text { поголовье, } \\
\text { в среднем } \\
\text { гол. }\end{array}$} \\
\hline & \multicolumn{2}{|c|}{$\mathrm{F} / \mathrm{F}$} & \multicolumn{2}{|c|}{$\mathrm{F} / \mathrm{V}$} & \multicolumn{2}{|c|}{$\mathrm{V} / \mathrm{V}$} & \\
\hline & гол. & $\%$ & гол. & $\%$ & гол. & $\%$ & \\
\hline 1 & 816 & 100,0 & 568 & 100,0 & 47 & 100,0 & 1431 \\
\hline 2 & 774 & 94,9 & 535 & 94,2 & 40 & 85,1 & 1349 \\
\hline 3 & 704 & 86,3 & 481 & 84,7 & 36 & 76,6 & 1221 \\
\hline 4 & 590 & 72,3 & 411 & 72,4 & 31 & 66,0 & 1032 \\
\hline 5 & 486 & 59,6 & 337 & 59,3 & 26 & 55,3 & 849 \\
\hline 6 & 372 & 45,6 & 270 & 47,5 & 20 & 42,6 & 662 \\
\hline 7 & 266 & 32,6 & 210 & 37,0 & 14 & 29,8 & 490 \\
\hline 8 & 175 & 21,4 & 156 & 27,5 & 6 & 12,8 & 337 \\
\hline 9 & 103 & 12,6 & 108 & 19,0 & 2 & 4,3 & 213 \\
\hline 10 & 59 & 7,2 & 66 & 11,6 & 2 & 4,2 & 128 \\
\hline 11 & 29 & 3,6 & 32 & 5,6 & 1 & 2,1 & 62 \\
\hline 12 & 12 & 1,5 & 20 & 3,5 & 0 & 0 & 30 \\
\hline 13 & 4 & 0,5 & 6 & 1,056 & 0 & 0,0 & 10 \\
\hline
\end{tabular}


тельность продуктивной жизни коров. Гетерозиготные (F/V) животные по сравнению с гомозиготными $(\mathrm{F} / \mathrm{F})$ первые пять лактаций имели незначительные расхождения по показателю выбытия. Их количество (337 коров) составило 59,3 \% от первоначальной выборки численностью 568 голов. Из 816 гомозиготных аналогов после первых пяти лактаций осталось 486 коров $(59,6 \%)$.

Начиная с продуктивного использования продолжительностью в 6 лактаций, группа гетерозигот имела преимущество. Из этой группы 19 \% коров лактировали 9 и более лактаций, что на 6,4 \% превышает соответствующий показатель первой группы животных (F/F). C возрастанием продолжительности жизни отмечали снижение разницы между этими двумя группами, но число коров с 13 и более лактациями в группе гетерозиготных животных в два раза превышало количество аналогичных животных первой (гомозиготной) группы.

В третьей группе коров, гомозиготных по $\mathrm{V}$-аллелю, уже после первой лактации выбыли $15 \%$ животных, что на 9,1 \% больше, чем в группе с гетерозиготным F-локусом. Только 12,8 \% коров этой группы использовали 8 лактаций, в то время как в группе с гетерозиготным локусом таких животных было 27,5 \%. У лучшей по продуктивному долголетию гомозиготной $(\mathrm{V} / \mathrm{V})$ коровы период использования в хозяйстве составил 11 лактаций, остальные животные с таким же генотипом выбыли после 10 лет хозяйственного использования.

Определили пожизненную молочную продуктивность коров в зависимости от генотипов в EAF-локусе. За всю продуктивную жизнь от гетерозиготных $(\mathrm{F} / \mathrm{V})$ животных надоили в среднем по $26452 \pm 919$ кг молока с содержанием жира $3,87 \pm 0,01 \%$ и белка $3,27 \pm 0,01 \%$, а надой лучшей коровы Чутки 438 за 9 лактаций (в течение 16 лет жизни) составил 75492 кг молока с содержанием жира и белка 3,8 и $3,2 \%$ соответственно.

От гомозиготных (F/F) коров получили в среднем по $23044 \pm 671$ кг молока с содержанием жира $3,87 \pm 0,01 \%$ и белка $3,28 \pm 0,01 \%$. Пожизненная (за 12 лактаций) продуктивность лучшей коровы Крепышки 488 с генотипом F/F - 72703 кг молока с содержанием жира 3,9\% и белка 3,3 \%.

Пожизненная молочная продуктивность гомозиготных $(\mathrm{V} / \mathrm{V})$ коров составила в среднем $25260 \pm 3330$ кг молока с содержанием жира $3,91 \pm 0,05 \%$ и белка 3,28 $\pm 0,04 \%$. Наиболее высокий показатель в этой группе отмечали у коровы Серьги 1489, от которой за 12 лактаций надоили 60421 кг молока с содержанием жира 3,75 \% и белка $3,1 \%$.

Результаты анализа показали, что между коровами с гетерозиготным локусом групп крови и сверстницами с гомозиготным локусом по количеству полученного в течение жизни молока имеются различия. Превосходство гетерозиготных $(\mathrm{F} / \mathrm{V})$ коров над гомозиготными $(\mathrm{F} / \mathrm{F})$ составило 3408 кг молока (разница достоверна), над гомозиготными $(\mathrm{V} / \mathrm{V})$ - 1192 кг.

Заключение. Результаты проведенных исследований дают основание утверждать, что на уровень молочной продуктивности коров бурой швицкой породы влияет состояние гетерогенности в локусах групп крови ЕАВ и ЕАF.

С увеличением молочной продуктивности первотелок снижается относительное количество гомозиготных животных. В исследованной популяции их численность в два раза ниже расчетных данных. Гетерозиготные в ЕАВ-локусе животные, возможно за счет неаддитивной изменчивости, имели в среднем превосходство над гомозиготными по надою молока за 305 дней первой лактации. Коровы с аллелем B $\mathrm{B}^{\mathrm{G} 01 \mathrm{T1Y2E} 3 \mathrm{~F}^{2} 2 \mathrm{G}^{\prime \prime} 2}$ в гомозиготном состоянии отличались повышенной молочной продуктивностью, а с рецессивным аллелем $\mathrm{b}$ - пониженной, предположительно из-за аддитивного влияния сцепленных с этими маркерами других генов генотипа, влияющих на уровень молочной продуктивности.

Коровы с гетерозиготным F/V-локусом групп крови по уровню удоя за 305 дней первой лактации (4849 кг), продолжительности продуктивного использования (свыше 13 лактаций), количеству молока, полученного за всю продуктивную жизнь коровы (26 452-75 792 кг), превосходили аналогов, гомозиготных в этом локусе.

Полученные результаты исследований необходимо использовать при совершенствовании бурого швицкого скота на повышение молочной продуктивности и продуктивного долголетия коров.

\section{СПИСОК ЛИТЕРАТУРЫ}

1. Анисимова Е.И. Иммуногенетические показатели в селекции крупного рогатого скота симментальской породы // Аграрная наука Евро-Северо-Востока. - 2019. - № 4. - С. 398-406.

2. Букаров Н.Г. Использование полиморфизма антигенов эритроцитов и главного комплекса тканевой совместимости в разведении и совершенствовании крупного рогатого скота: автореф. дис. ... д-ра биол. наук. - Дубровицы, 1995. - 33 с.

3. Генетический контроль селекционных процессов в популяции бурого швицкого скота с использованием маркерных генов групп крови / М.Е. Гонтов [и др.] // Молочное и мясное скотоводство. - 2016. № 4. - C. 17-20.

4. Гомо- и гетерозиготность популяции скота смоленского типа бурой швицкой породы / М.Е. Гонтов [и др.] // Аграрный научный журнал. - 2019. - № 10. C. $17-20$.

5. Гонтов М.Е., Дмитриева В.И. Оценка генотипов животных с использованием маркерных генов групп 
крови // Актуальные проблемы животноводства и пути их решения: материалы Междунар. науч.-практ. конф. - Смоленск, 2010. - С. 27-29.

6. Дмитриева В.И., Кольцзов Д.Н., Гонтов М.Е. Аллели ЕАВ-локуса групп крови в селекции крупного рогатого скота по продуктивности // Аграрный вестник Юго-Востока. - 2018. - № 1 (18). - С. 10-13.

7. Животовский Л.А. Методические рекомендации по статистическому анализу иммуногенетических данных для использования в селекции животных. Дубровицы, 1974. - 30 с.

8. Иммуногенетический мониторинг при выведении и совершенствовании типа «Смоленский» бурого швицкого скота в Смоленской области / M.Е. Гонтов [и др.] // Достижения науки и техники АПК. - 2011. - № 3. - С. 54-56.

9. Иммуногенетический анализ линий бурого швицкого скота / М.Е. Гонтов [и др.] // Аграрный научный журнал. - 2020. - № 4. - С. 55-60.

10. Марзанова Л.К., Попов Н.А. Контроль за генетической изменчивостью в стадах молочных пород / / Молочное и мясное скотоводство. - 2018. - № 8. С. $16-18$.

11. Плохинский Н.А. Биометрия. - М.: Изд-во Моск. ун-та, 1970. - 367 с.

12. Применение разработанной системы использования групп крови на этапах селекции бурого швицкого скота в Смоленской области / М.Е. Гонтов [и др.] // Достижения науки и техники АПК. - 2015. - Т. 29. № 9. - С. 86-89.

13. Продуктивное долголетие крупного рогатого скота молочных пород / Н.И. Стрекозов [и др.] // Аналитический обзор. - Дубровицы, 2012. - 72 с.

14. Продуктивное долголетие коров и влияние на него ряда факторов / В.И. Дмитриева [и др.] // Зоотехния. - 2009. - № 7. - С. 18-20.

15. Рекомендации по использованию методов ге- нетического мониторинга в селекции крупного рогатого скота и свиней / А. А. Новиков [и др.]. - Лесные Поляны, 2015. - 23 с.

16. Система иммуногенетических маркеров при совершенствовании новых молочных типов бурого швицкого и сычевского скота / В.К. Чернушенко [и др.]. - Смоленск: Смоленская городская типография, 2010. - 47 с.

17. Сороковой П.Ф. Методические рекомендации по исследованию групп крови в селекции крупного рогатого скота. - Дубровицы, 1974. - 40 с.

18. Чернушенко В.К. Повышение эффекта селекции молочного скота при использовании иммуногенетических маркеров: дис. ... д-ра с.-х. наук. - Смоленск, 1992. - 315 с.

19. Эффективность мониторинга групп крови на этапах селекции сычевской породы крупного рогатого скота в Смоленской области / Д.Н. Кольцов [и др.] // Достижения науки и техники АПК. - 2015. - Т. 29. № 9. - С. 44-46.

Гонтов Михаил Елисеевич, канд. с.-х. наук, доиент, ведущий научный сотрудник лаборатории зоотехнологий, Федеральное государственное бюджетное научное учреждение «Федеральный научный иентр лубяных культур». Россия.

Кольцов Дмитрий Николаевич, канд. с.-х. наук, доцент, заместитель директора по региональному развитию, Федеральное государственное бюджетное научное учреждение «Федеральный научный иентр лубяных культур». Россия.

214025, г. Смоленск, ул. Нахимова, 21.

Тел.: (4812) 66-29-41.

Ключевые слова: молочная продуктивность; долголетие; гетерозиготность; бурая швиикая порода; группы крови; локус.

\section{MILK PRODUCTIVITY AND HETEROGENEITY IN EAB, EAF LOCI OF BROWN SWISS CATTLE}

Gontov Mikhail Eliseevich, Candidate of Agricultural Sciences, Associate Professor, Leading Researcher, Federal Research Center for Bast Fiber Crops, Russia.

Koltsov Dmitry Nikolaevich, Candidate of Agricultural Sciences, Associate Professor, Leading Researcher, Federal Research Center for Bast Fiber Crops, Russia.

Keywords: dairy efficiency; longevity; heterozygosity; Brown Swiss; blood groups; locus.

The article presents the results of study the dairy efficiency of Brown Swiss cattle in the Smolensk region depending on the homozygous and heterozygous state of marker genes EAB and EAF loci of blood groups. The research was carried out using standard immunogenetic and statistical methods with the use of proprietary reagents. It was found that with an increase in the dairy efficiency heifer in the population, the relative number of animals homozygous in the EAB locus decreases, and their lack is revealed. Heterozygous animals were superior to homozygous animals in milk yield for 305 days of first lactation. A group of cows homozygous for the BG301T1Y2E'3F'2G allele had increased dairy efficiency and homozygous for the recessive EAB locus allele had decreased dairy efficiency. Animals that were heterozygous for the F / V-locus of blood groups, in terms of milk yield for 305 days of first lactation (4849 $\mathrm{kg}$ ), duration of productive use (over 13 lactations), and the amount of milk received during the entire productive life of a cow (26 $452-75792 \mathrm{~kg})$, were superior to analogues that were homozygous for this locus. 